\title{
Phenology and Yield Response of Zea mays L. to Mineral Phosphorous under Semiarid Climate
}

\author{
Waqas Liaqat ${ }^{1 *}$, Haseeb Ahmad ${ }^{1}$, Muhammad Faheem Jan ${ }^{1}$, Wazir Rehan ${ }^{2}$ and Muhammad Dawood Ahmadzai ${ }^{1}$ \\ ${ }^{1}$ Department of Agronomy, The University of Agriculture, Pakistan \\ ${ }^{2}$ Agricultural Research Institute Tarnab, Pakistan
}

Submission: March 02, 2018; Published: April 03, 2018

"Corresponding author: Waqas Liaqat, Faculty of Crop Production Sciences, Department of Agronomy, The University of Agriculture, Peshawar, Pakistan, Tel: 0316-9527673; Email: waqasliaqat@aup.edu.pk

\begin{abstract}
Soil phosphorous (P) limitation is one of the most important constraint to food production in Pakistan. An experiment was conducted at Agricultural Research Institute Tarnab, Peshawar during kharif 2016 with an objective to determine best level of P for higher maize yield. Treatments comprised of six P levels $\left(0,35,70,105,140\right.$ and $\left.175 \mathrm{~kg} \mathrm{ha}^{-1}\right)$ laid out in randomized complete block design having three replications. Maize hybrid Babar was sown in six rows, $0.70 \mathrm{~m}$ apart in a plot size of $4.2 \mathrm{mx} 3.9 \mathrm{~m}$. Nitrogen and Potassium was applied at the rate of 200 and $80 \mathrm{~kg} \mathrm{ha}^{-1}$ respectively. Crop phenology (days to tasseling, silking and maturity) and yield of maize is significantly affected by mineral phosphorous. Crop phenology was inversely affected by P levels i.e. increasing P from $0 \mathrm{~kg} \mathrm{ha}^{-1}$ onwards decreased days to phenology in maize. Phosphorous applied @ of $175 \mathrm{~kg} \mathrm{ha}^{-1}$ resulted in highest thousand grains weight, biological yield and grain yield which was statistically not different from 140 $\mathrm{kg} \mathrm{ha}^{-1} \mathrm{P}$ application. Application of mineral P @ of $140 \mathrm{~kg} \mathrm{ha}^{-1}$ gave higher yield under the climatic conditions of Peshawar region.
\end{abstract}

Keywords: Babar; Days to maturity; Thousand grain weight; Grain yield

\section{Introduction}

Maize, being highly exhaustive crop is very responsive towards phosphorous (P) application. It takes $\mathrm{P}$ throughout its life cycle with maximum uptake between third and fifth week of the growing period [1]. It readily moves from older tissues to younger tissues due to its mobility within the plant and as a result growth of root, leaves and stem occurs [2]. It has a significant role in plant reproductive growth and is second limiting macro nutrient after $\mathrm{N}$ in most soils [3]. Adequate $\mathrm{P}$ application improves plant growth and development hence results in early maturity [4]. Due to rapid adsorption of phosphate by aluminium and iron oxides, less than $1 \%$ of $\mathrm{P}$ present in soil is absorbed by plant roots [5]. More than $80 \%$ of Pakistani soils are deficient in P [4]. Maize yield in Pakistan and particularly in Khyber Pakhtunkhwa (KP) is still very low than other countries. Among numerous reasons for low maize yield, inappropriate use of fertilizers is also the one. Soils of KP are alkaline (pH 7 to 9) and high in calcium carbonate [6]. Calcium activity in such soils decreased P solubility and thus more P should be added to meet crop demand [7]. The present research was designed with the aim to study the phenology and yield response of maize hybrid under various levels of Phosphorous.

\section{Materials and Methods}

An experiment wasinitiated to study the performance of maize against different phosphorous levels. Experiment was carried out at Agriculture Research Institute Tarnab, Peshawar during kharif 2016. One factor i.e. phosphorous with six $(0,35,70,105$, 140 and $175 \mathrm{~kg} \mathrm{ha}^{-1}$ ) levels was studied. Experiment was laid out in randomized complete block design having three replications. Each subplot was $4.2 \mathrm{~m} \times 3.9 \mathrm{~m}$ consisting of six rows with $0.75 \mathrm{~m}$ distance among rows. Maize hybrid Babar was sown manually on 23 June. Basic dose Nitrogen and Potassium were applied @ of 200 and $80 \mathrm{~kg} \mathrm{ha}^{-1}$ respectively. Nitrogen was applied from urea at sowing, two and six weeks after sowing in equal splits. Complete dose of K was applied during seedbed preparation from sulphate of potash. Three hoeings with fifteen days interval after sowing was done for weeds removal. Recommended cultural practices were kept same for all experimental units. Data on days to tasseling and silking were recorded from sowing day to date till $80 \%$ plants produced tassels and silks in each subplot. The data were registered by visually observing the plants. The maturity of crop was observed when black scar appears at the base of each grain in each experimental unit. Eight ears were selected 
from different location in each subplot and rows in these ears were counted and averaged to determine rows per ear. Ears per plant was recorded by counting ears on eight random plants in each subplot and averaged. After shelling, cleaned thousand grains were taken from each plot and weighed with balance to determine thousand grains weight. For biological (biomass) yield four middle rows in each plot were harvested at harvest maturity, sun dried for five days. After sun drying they were weighed with digital balance for each subplot. Grain yield was measured by removing ears from plants harvested for biomass yield. Ears were shelled to determine grain yield per sampled area. The data was converted to $\mathrm{kg} \mathrm{ha}^{-1}$. The recorded data were statistically examined under the technique documented by [8] as appropriate for RCB design. Least significant difference test was used to compare means when F-test resulted significant.

\section{Results and Discussion}

\section{Crop phenology}

Phenology of maize is significantly affected by mineral phosphorous presented in (Table 1). Mean values showed that days to phenology decreased with increase in $\mathrm{P}$ levels from $0 \mathrm{~kg} \mathrm{ha}{ }^{-1}$ onwards. Early tasseling, silking and maturity were observed in plots which received highest dose of mineral $\mathrm{P}$ $\left(175 \mathrm{~kg} \mathrm{ha}^{-1}\right)$ which was statistically similar with plots received Table 1: Means of days to tasseling (DTT), days to silking (DTS), days to physiological maturity (DPM), rows per ear (RPE), ears per plant (EPP), thousand grains weight (TGW), biological yield (BY) and grain yield (GY) of maize hybrid as affected by Phosphorous levels.

NS = Non significant

\begin{tabular}{|c|c|c|c|c|c|c|c|c|}
\hline Treatments & DTT & DTS & DPM & RPE & EPP & TGW (g) & BY(t ha-1) & GY(t ha-1) \\
\hline \multicolumn{9}{|c|}{ Phosphorous levels (kg ha-1) } \\
\hline 0 & $62 \mathrm{a}$ & $68 a$ & $108 \mathrm{a}$ & 14 & 1.2 & $296 \mathrm{e}$ & $10 \mathrm{e}$ & $3.7 \mathrm{~d}$ \\
\hline 35 & $60 \mathrm{a}$ & $67 a$ & $105 b$ & 14 & 1.2 & 299de & $11.2 \mathrm{~d}$ & $4.1 \mathrm{c}$ \\
\hline 70 & $58 \mathrm{~b}$ & $65 b$ & $104 \mathrm{~b}$ & 14 & 1.3 & $304 \mathrm{~cd}$ & $13.2 \mathrm{c}$ & $4.6 \mathrm{~b}$ \\
\hline 105 & $55 c$ & $63 c$ & $101 c$ & 14 & 1.3 & $309 b c$ & $14.7 \mathrm{~b}$ & $4.9 \mathrm{~b}$ \\
\hline 140 & $52 d$ & $59 d$ & $96 d$ & 14 & 1.3 & $314 \mathrm{ab}$ & $17 \mathrm{a}$ & $5.5 \mathrm{a}$ \\
\hline 175 & $51 d$ & $58 d$ & $95 d$ & 14 & 1.3 & $315 a$ & $17.4 \mathrm{a}$ & $5.6 a$ \\
\hline LSD (0.05) & 2.01 & 1.78 & 2.56 & NS & NS & 5 & 0.62 & 0.36 \\
\hline
\end{tabular}

\section{Thousand grains weight $(\mathrm{g})$}

Thousand grains weight was significant for P levels (Table 1). Data showed that maximum grain weight was recorded for highest level of P (175kg ha-1) which was statistically alike with $140 \mathrm{~kg} \mathrm{ha}^{-1} \mathrm{P}$ treated plots. Minimum grain weight was recorded in control plots which were statistically similar to $35 \mathrm{~kg} \mathrm{P} \mathrm{ha}^{-1}$ application. Phosphorous application improves root growth and health which in turn increases the absorption of nutrients and water from soil thus, increases grain weight. [10] reported minimum grain weight in plots receiving no P. [9] documented heavier grains for higher level of $\mathrm{P}$ and lighter grains for lower rate of $\mathrm{P}$ application.

\section{Biological yield ( $\mathrm{t} \mathrm{ha}^{-1}$ )}

The impact of $\mathrm{P}$ levels on biological yield of maize was significant (Table 1). Highest biomass yield was recorded
$140 \mathrm{~kg} \mathrm{P} \mathrm{ha-1}$. More days to phenology were observed in control plots. An inverse relationship was found between $P$ and maize phenology. With increase in P levels days to phenology decreased further increase in $P$ did not cause significant changes in maize phenology. Phosphorous application enhances root growth and helps plant to uptake more $\mathrm{P}$ and other nutrients from soil. Thus, causes early phenological development and rapid crop growth to complete its life cycle. [6] reported that increase in P decreases days to phenology of maize.

\section{Rows per ear}

Phosphorous levels had no significant effect on rows per ear of maize crop (Table 1). Our findings are not in line with those of [9] who indicated significant variations in rows per ear and documented more rows per ear for $120 \mathrm{~kg} \mathrm{ha}^{-1} \mathrm{P}$ application against less rows recorded in control plots.

\section{Ears per plant}

Ears per plant were not significantly affected by various $P$ levels (Table 1). Our outcomes are different from results of [4] who reported variations in ears per plant for different $P$ levels and reported more ears per plant for $\mathrm{P}$ applied at the rate of $100 \mathrm{~kg} \mathrm{ha}^{-1}$. accordingly up to $\mathrm{P}$ applied at the rate of $140 \mathrm{~kg} \mathrm{ha}^{-1}$ and

for plots which received P @ of $175 \mathrm{~kg} \mathrm{ha}^{-1}$ followed by $140 \mathrm{~kg}$ $\mathrm{ha}^{-1}$ with no significant differences. Lowest value for biomass yield was recorded in plots treated with no $\mathrm{P}$ (control plots). Phosphorous helps in development of strong and healthy root system which results in efficient uptake of essential nutrients required for maximum dry matter production. Absence of $\mathrm{P}$ in control plots did not develop healthy root system to facilitate better and timely absorption of nutrients and water thus led to lower dry matter production. [9] documented that as level of $\mathrm{P}$ increases biological yield also increases.

\section{Grain yield ( $\mathrm{t} \mathrm{ha}^{-1}$ )}

Significant variations were recorded in maize grain yield treated with different P levels (Table 1). Highest grain yield was recorded in plots treated with $175 \mathrm{~kg} \mathrm{ha}^{-1} \mathrm{P}$ which was similar with plots treated with $140 \mathrm{~kg} \mathrm{ha}^{-1} \mathrm{P}$. Grain yield obtained from 
$105 \mathrm{~kg} \mathrm{ha}^{-1}$ and $70 \mathrm{~kg} \mathrm{ha}^{-1} \mathrm{P}$ application did not vary significantly from each other. Lowest grain yield was recorded from control plots. Phosphorous application enhanced root growth and developed strong root system to absorb more nutrients and water which resulted in more grain yield. Poor root system due to no $\mathrm{P}$ application in control plots might be the reason for lower grain yield. [4] recorded maximum grain yield at higher level of $\mathrm{P}$ while minimum grain yield at lower level of $\mathrm{P}$.

\section{Conclusion}

From the research conducted, it can be concluded that among various studied P levels highest level of P i.e. $175 \mathrm{~kg} \mathrm{ha}^{-1}$ resulted in maximum biological and grain yield but it was statistically similar with $\mathrm{P}$ applied at the rate of $140 \mathrm{~kg} \mathrm{ha}^{-1}$. Thus, application of $140 \mathrm{~kg} \mathrm{ha}^{-1} \mathrm{P}$ is economical and suggested for achieving higher yield under agro-climate of Peshawar region.

\section{References}

1. Ali J, Bakht J, Shafi M, Khan S, Shah WA (2002) Uptake of nitrogen as affected by various combinations of nitrogen and phosphorus. Asian J Plant Sci 1(4): 367-369.

2. Ali M (2012) Integrated management of phosphorus and potassium for maize (Zea mays L.). Ph.D. dissertation, University of Agriculture Faisalabad, Pakistan.

3. Wojnowska T, Panak H, Seikiewiez S (1995) Reaction of winter oil seed rape to increasing levels of nitrogen fertilizer application under condition of Ketizyn Chernozem. Rosling Oleiste 16: 173-180.
4. Masood T, Gul R, Munsif F, Jalal F, Hussain Z, et al. (2011) Effect of different phosphorus levels on the yield and yield component of maize. Sarhad J Agric 27(2): 167-170.

5. Xavier, FA, Almeida EF, Cardoso IM, Mendonça EDS (2011) Soil phosphorus distribution in sequentially extracted fractions in tropical agroecosystems in the Atlantic forest biome, southeastern Brazil. Nutr Cycl Agroecosyst 89(1): 31-44.

6. Amanullah, Zakirullah M, Khalil SK (2010) Timing and rate of phosphorus application influence maize phenology, yield and profitability in Northwest Pakistan. Int J Plant Prod 4(4): 281-292.

7. Ibrikci, H, Ryan J, Ulger AC, Buyuk G, Cakir B, et al. (2005) Maintenance of P fertilizer and residual P effect on corn production. Nigerian J Soil Sci 2: 1279-286

8. Jan MT, Shah P, Hollington PA, Khan MJ, Sohail Q (2009) Agriculture Research: Design and Analysis. A monograph Agric Univ Pesh Pak.

9. Sadiq G, Khan AA, Inamullah, Rab A, Fayyaz H, et al. (2017) Impact of phosphorus and potassium levels on yield and yield components of maize. Pure Appl Biol 6(3): 1071-1078.

10. Hussain N, Khan AZ, Akbar H, Akhtar S (2006) Growth factors and yield of maize as influenced by phosphorus and potash fertilization. Sarhad J Agric 22(4): 579-583. 